\footnotetext{
1) Department of Genetics and Animal Breeding, Agricultural University of Poznan, Poland

${ }^{2)}$ National Research Institute of Animal Production, Poultry Research Branch at Zakrzewo, Poland
}

\title{
Genetic evaluation of laying hens under fixed regression animal models
}

\begin{abstract}
Monthly egg production in laying hens was studied under fixed regression models. The data of 37071 birds from three strains under long term selection were analysed. The covariates from four production curves were included in nested and non-nested form. From linearized functions the model of Ali and Schaeffer most adequately described the egg production. Akaike Information Criterion favoured models with nested covariates. The following genetic parameters were estimated: heritability $0.02-0.2,0.03-0.06,0.03-0.20$ repeatability $0.11-0.23$, 0.21-0.30, 0.34-0.43 for A22, A88 and K66 lines, respectively. In conclusion, regression models could be considered in genetic evaluation of laying hens.
\end{abstract}

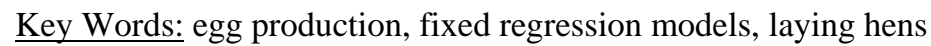

\section{Zusammenfassung}

Titel der Arbeit: Zuchtwertschätzung bei Legehennen mit fixen Regressionstiermodellen

Es wurden die monatlichen Legeleistungen von 37071 Hennen aus drei Langzeitselektionslinien mit Hilfe fixer Regressionsmodelle untersucht. Die Kovariablen von vier Leistungskurven wurden als hierarchische und nicht hierarchische Form einbezogen. Von den linearen Regressionsfunktionen wurde die Eiproduktion am besten von dem Modell nach Ali und Schaeffer (polynominale Regression) beschrieben. Akaike Informationskriterien bevorzugten Modelle mit hierarchischen Kovariablen. Folgende genetischen Parameter konnten bei den Tieren der drei Linien A22, A88 und K66 für die monatliche Eiproduktion geschätzt werden: $h^{2}$ 0,02-0,2, 0,03-0,06, 0,03-0,20 bzw. Wiederholbarkeit 0,11-0,23, 0,21-0,30, 0,34-0,43. Der Vergleich fixer Regressionsmodelle konnte für eine genetische Einschätzung von Legehennen genutzt werden.

Schlüsselwörter: Eiproduktion, fixe Regressionsmodelle, Legehennen

\section{Introduction}

In $\mathrm{XX}^{\text {th }}$ century genetic evaluation of laying hens on egg production was usually based on single measurement-cumulative production. Such an approach was recommended due to simplicity and relatively small computing demands. However, egg production is a trait that is expressed over a long trajectory of time and as such undergoes both genetic and environmental effects. Knowledge about the patterns of egg-laying might contribute to more accurate prediction of genetic effects. There are several studies on monthly egg production reporting genetic parameters (ZIĘBA, 1990; PREISINGER and SAVAS, 1997; SAVAS et al., 1998; ANANG et al., 2000; NURGIARTININGSIH et al., 2002, 2005). In the last years the rapid development of regression methodology is observed. It provides a tool to analyse longitudinal records in animal breeding that reveal specific patterns of change over a trajectory. Regression models have already been implemented in dairy cattle breeding programs (SCHAEFFER et al., 2000, AMIN 2001), but their possible advantages, like higher accuracy of selection, the use of information on course of traits, and the possibility to 
change course of trait through selection have been also suggested for other farm animals like pigs (HUISMAN, 2002) and sheep (HORSTICK and DISTL, 2002). It is well known, that although it is not steady process over time, egg production in poultry shows a regularity, that is generally denoted as the egg production curve, especially when summarised on a weekly or monthly basis in a group of hens (YANG et. al., 1989). To describe trajectory of production curves over time many regression models have been suggested (JAMROZIK et al, 1997). An average egg production curve can be included as the fixed or random part of the model. In second case, the individual genetic curve is estimated for each bird. Using such approach the birds with most desired laying trace can be selected. The biologically meaningful curve parameters like persistency or decreasing slope can be directly selected for.

The objective of this study was to estimate genetic parameters of monthly egg production under fixed regression model. Goodness of fit of some egg production curves was examined as well.

\section{Material and methods}

The laying performance data of three lines (denoted as A22, A88 and K66) from Poultry Research Branch at Zakrzewo were analyzed. Birds were kept in single cages with environmental factors e.g. light, temperature, humidity, and feeding automatically controlled according to standard schedules. Altogether 37071 hens (13770 of A22, 13950 of A88 and 9351 of K66) were recorded in six generations. From crossbreeding perspective two of the lines (A22 and A88) are maternal - Rhode Island White lines selected on egg production and shell colour. The third line (K66) is a paternal Rhode Island Red line selected on egg weight and shell colour. Brief statistical description of the analyzed populations was given on Figure 1.

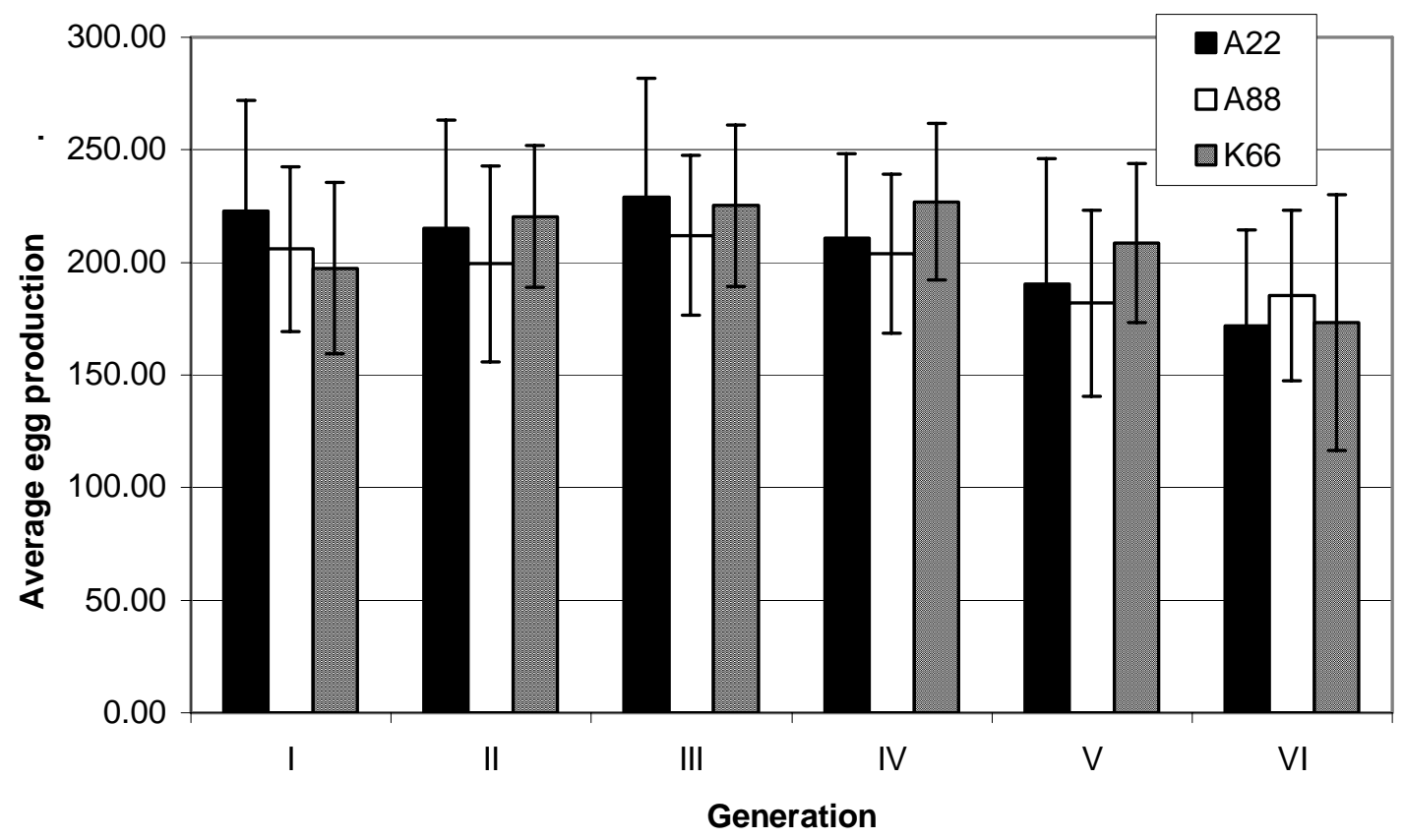

Fig. 1: Average egg production of the studied populations within generations (Durchschnittliche Eiproduktion der untersuchten Populationen innerhalb der Generationen) 
As the lines were purebreds the data was analyzed within lines. The daily records were cumulated into monthly production from fixed day of minimum $5 \%$ egg production in given line.

The analysis was performed based on two classes of fixed regression animal models. First group models can be noted as follow:

$\mathrm{y}_{\mathrm{ijkl}}=H Y_{\mathrm{i}}+\mathrm{f}(\mathrm{x})_{\mathrm{j}}+\mathrm{a}_{\mathrm{k}}+\mathrm{p}_{\mathrm{k}}+\mathrm{e}_{\mathrm{ijkl}}$

where: $y_{i j k l}$ is a number of eggs per month within hatch period - generation (year) group for the k-th layer, $\mathrm{HY}_{\mathrm{i}}$ is a fixed effect of hatch period - year group, $\mathrm{f}(\mathrm{x})_{\mathrm{i}}-$ fixed effect of consecutive month (included as respective egg production curve - see below); $a_{k}$ is a random additive genetic effect; $p_{k}$ is a random permanent environmental effect, $\mathrm{e}_{\mathrm{ijkl}}$ is a residual effect connected with ijkl-th observation.

Second class of models included covariates nested within hatch period - year groups. Thus:

$\mathrm{y}_{\mathrm{ijkl}}=\operatorname{HY}\left[\mathrm{f}(\mathrm{x})_{\mathrm{j}}\right]_{\mathrm{i}}+\mathrm{a}_{\mathrm{k}}+\mathrm{p}_{\mathrm{k}}+\mathrm{e}_{\mathrm{ijkl}}$

where: $\operatorname{HY}\left[f(x)_{j}\right]_{i}$ is the fixed effect of covariate nested within hatch period - year group, $\mathrm{y}_{\mathrm{ijkl}}, \mathrm{a}_{\mathrm{k}}, \mathrm{p}_{\mathrm{k}}$ and $\mathrm{e}_{\mathrm{ijkl}}$ - as above.

Goodness of fit of the models was checked by Akaike Information Criterion (AKAIKE, 1977). Variance components were estimated by the use of the Average Information Restricted Maximum Likelihood algorithm (JOHNSON and THOMPSON, 1995). The DFREML package program (MEYER, 2001) was employed. The following models were used to describe average production curves:

exponential model: $\quad f(x)=a+b x+c \exp \left(-\frac{1}{2} x\right)$

(WILMINK, 1987),

mixed log model $\quad f(x)=a+b x^{0.5}+c \ln x$

(GUO and SWALVE, 1995),

polynomial regression $f(x)=a+b\left(\frac{x}{n}\right)+c\left(\frac{x}{n}\right)^{2}+d \ln \left(\frac{n}{x}\right)+e\left(\ln \left(\frac{n}{x}\right)\right)^{2} \quad$ (ALI and SCHAEFFER, 1987),

Yang model $\quad f(x)=\frac{a \exp ^{-b t}}{1+\exp ^{-c(t-d)}}$ (YANG et al., 1989),

fourth order polynomial $\mathrm{f}(x)=a+b x+c x^{2}+d x^{3}+e x^{4}$

where $\mathrm{y}$ is the production in time $x, a, b, c, d$, $e$ are the parameters estimated in the models.

Curves were compared based on the adjusted coefficient of multiple determination $\left(\mathrm{R}_{\mathrm{a}}{ }^{2}\right)$, which indicates which part of sum of squares can be eliminated by using multiple regression equation with adjustment for the number of parameters in the model (SHERROD, 1998) and Durbin-Watson statistics (D-W), which is used to test for the presence of the first-order autocorrelation in the residuals of a regression equation (JENSEN, 2005). The NLREG program (SHERROD, 1998) was used to asses goodness of fit of the curves. 
Results

Average egg production curves were shown on Figure 2. K66 line showed the most desired shape of the egg production curve with the peak production of $91.2 \%$ achieved already in the second month of lay and the highest persistency (both defined as number of weeks in which the highest production is maintained or as the decreasing slope after the peak).

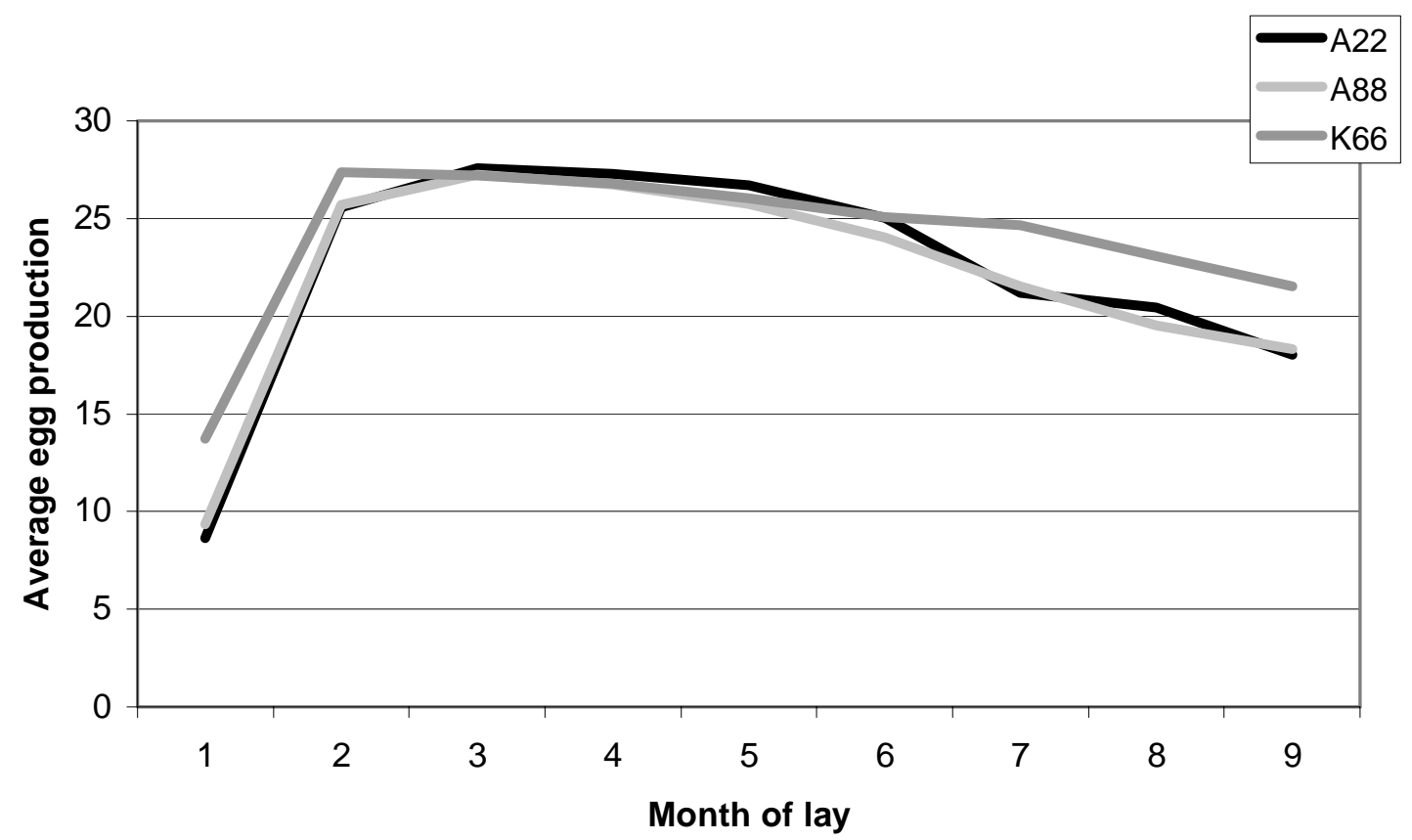

Fig. 2: Average egg production curves within lines (Kurven der monatlichen Eierleistung nach Selektionslinien)

Table 1

Adequacy of chosen mathematical models to describe egg production in the studied populations (Güte der verglichenen mathematischen Modelle hinsichtlich der dargestellten Eierleistungen)

\begin{tabular}{ccccc}
\hline \multirow{2}{*}{ model } & \multirow{2}{*}{ Goodness of fit criterion } & \multicolumn{3}{l}{ line } \\
\cline { 3 - 5 } & & $\mathrm{A} 22$ & $\mathrm{~A} 88$ & $\mathrm{~K} 66$ \\
\hline \multirow{2}{*}{ Ali and Schaeffer } & $\mathrm{R}_{\mathrm{a}}{ }^{2}$ & 0.97 & 0.98 & 0.89 \\
& $\mathrm{D}-\mathrm{W}$ & 2.70 & 2.28 & 2.15 \\
Guo and Swalve & $\mathrm{R}_{\mathrm{a}}{ }^{2}$ & 0.95 & 0.94 & 0.87 \\
& $\mathrm{D}-\mathrm{W}$ & 2.07 & 1.83 & 2.03 \\
Wilmink & $\mathrm{R}_{\mathrm{a}}{ }^{2}$ & 0.87 & 0.84 & 0.75 \\
4th order Polynomial & $\mathrm{D}-\mathrm{W}$ & 1.96 & 1.86 & 2.05 \\
& $\mathrm{R}_{\mathrm{a}}{ }^{2}$ & 0.94 & 0.94 & 0.90 \\
Yang & $\mathrm{D}-\mathrm{W}$ & 2.53 & 2.49 & 2.72 \\
& $\mathrm{R}_{\mathrm{a}}{ }^{2}$ & 0.97 & 0.98 & 0.99 \\
\hline
\end{tabular}

The highest peak production 92\% was recorded in A22 line in the third month of lay however due to faster decrease after the peak this line showed lower overall production. The egg production curve of A88 line was similar to the other Road Island White line with slightly lower production level. Goodness of fit criteria for the chosen mathematical models were included in Table 1. Except for the Wilmink's function the adjusted coefficient of multiple determination was about 0.9 . 
Table 2

Genetic parameters of monthly egg production in the studied populations (Genetische Parameter der monatlichen Eiproduktion bei den drei Selektionslinien)

\begin{tabular}{|c|c|c|c|c|c|c|c|}
\hline \multirow{2}{*}{ Model } & \multirow{2}{*}{$\begin{array}{l}\text { Egg production } \\
\text { curve }\end{array}$} & \multicolumn{2}{|c|}{ A22 } & \multicolumn{2}{|c|}{ A88 } & \multicolumn{2}{|c|}{ K66 } \\
\hline & & $h^{2} \pm S E$ & $\mathrm{r} \pm \mathrm{SE}$ & $\mathrm{h}^{2} \pm \mathrm{SE}$ & $r \pm S E$ & $\mathrm{~h}^{2} \pm \mathrm{SE}$ & $\mathrm{r} \pm \mathrm{SE}$ \\
\hline \multirow{4}{*}{$\begin{array}{l}\text { without hatch- } \\
\text { year effect }\end{array}$} & Ali and Schaeffer & $0.0969 \pm 0.0050$ & $0.2124 \pm 0.0037$ & $0.0591 \pm 0.0094$ & $0.2674 \pm 0.0054$ & $0.2010 \pm 0.0148$ & $0.4336 \pm 0.0056$ \\
\hline & Polynomial & $0.1016 \pm 0.0063$ & $0.2027 \pm 0.0035$ & $0.0583 \pm 0.0093$ & $0.2616 \pm 0.0054$ & $0.1979 \pm 0.0146$ & $0.4230 \pm 0.0056$ \\
\hline & Guo and Swalve & $0.1013 \pm 0.0063$ & $0.2016 \pm 0.0035$ & $0.0586 \pm 0.0093$ & $0.2641 \pm 0.0054$ & $0.1950 \pm 0.0144$ & $0.4131 \pm 0.0056$ \\
\hline & Wilmink & $0.0840 \pm 0.0053$ & $0.1459 \pm 0.0031$ & $0.0590 \pm 0.0094$ & $0.2666 \pm 0.0054$ & $0.1887 \pm 0.0139$ & $0.3942 \pm 0.0056$ \\
\hline \multirow{4}{*}{$\begin{array}{l}\text { with regression } \\
\text { non-nested in } \\
\text { hatch-year }\end{array}$} & Ali and Schaeffer & $0.0243 \pm 0.0032$ & $0.1651 \pm 0.0028$ & $0.0265 \pm 0.0060$ & $0.2349 \pm 0.0049$ & $0.0297 \pm 0.0064$ & $0.3805 \pm 0.0044$ \\
\hline & Polynomial & $0.0239 \pm 0.0032$ & $0.1608 \pm 0.0028$ & $0.0261 \pm 0.0059$ & $0.2294 \pm 0.0048$ & $0.0291 \pm 0.0063$ & $0.3699 \pm 0.0044$ \\
\hline & Guo and Swalve & $0.0238 \pm 0.0032$ & $0.1597 \pm 0.0028$ & $0.0263 \pm 0.0060$ & $0.2318 \pm 0.0049$ & $0.0286 \pm 0.0061$ & $0.3600 \pm 0.0044$ \\
\hline & Wilmink & $0.0196 \pm 0.0026$ & $0.1091 \pm 0.0024$ & $0.0253 \pm 0.0057$ & $0.2188 \pm 0.0048$ & $0.0275 \pm 0.0059$ & $0.3413 \pm 0.0043$ \\
\hline \multirow{4}{*}{$\begin{array}{l}\text { models with } \\
\text { regresion } \\
\text { nested within } \\
\text { hatch-year }\end{array}$} & Ali and Schaeffer & $0.0306 \pm 0.0041$ & $0.2412 \pm 0.0032$ & $0.0311 \pm 0.0070$ & $0.2972 \pm 0.0053$ & $0.0310 \pm 0.0067$ & $0.4099 \pm 0.0045$ \\
\hline & Polynomial & $0.0299 \pm 0.0039$ & $0.2319 \pm 0.0032$ & $0.0305 \pm 0.0069$ & $0.2882 \pm 0.0052$ & $0.0302 \pm 0.0065$ & $0.3938 \pm 0.0044$ \\
\hline & Guo and Swalve & $0.0290 \pm 0.0038$ & $0.2211 \pm 0.0031$ & $0.0302 \pm 0.0068$ & $0.2847 \pm 0.0052$ & $0.0296 \pm 0.0064$ & $0.3813 \pm 0.0044$ \\
\hline & Wilmink & $0.0234 \pm 0.0031$ & $0.1535 \pm 0.0027$ & $0.0291 \pm 0.0066$ & $0.2693 \pm 0.0051$ & $0.0284 \pm 0.0061$ & $0.3605 \pm 0.0044$ \\
\hline
\end{tabular}


Slightly worse performance of Wilmik's curve results from the fact that it has only three parameters to describe the data. For K66 line the curves, except for Yang's model, did not follow the rapid increasing phase at the beginning of production. Because the Yang's function can not be linearized it was not used as a part of regression models.

Heritability estimates were listed in Table 2. Generally, the heritability of egg production in the studied populations was low. It ranged from 0.02 to $0.1,0.02$ to 0.06 , 0.03 to 0.2 for A22, A88 and K66 lines, respectively.

From the groups of models Akaike Information Criterion favours the models with covariates nested within hatch-year classes (see Table 3).

Table 3

Adequacy of the analysed regression models (Adäquanz der analysierten Regressionsmodelle)

\begin{tabular}{ccccc}
\hline \multirow{2}{*}{ Model } & Egg production curve & \multicolumn{2}{c}{ Akaike information Criterion } \\
& & A22 & A88 & K66 \\
\hline \multirow{2}{*}{ without hatch-year effect } & Ali and Schaeffer & 599910 & 263874 & 358672 \\
& Polynomial & 602120 & 265012 & 361550 \\
& Guo and Swalve & 602618 & 264490 & 364164 \\
& Wilmink & 631486 & 264022 & 369158 \\
\hline with regression non-nested in & Ali and Schaeffer & 598436 & 263286 & 358080 \\
hatch-year & Polynomial & 600784 & 264428 & 360958 \\
& Guo and Swalve & 601284 & 263906 & 363570 \\
models with regresion nested & Wilmink & 630152 & 266500 & 368564 \\
\hline within hatch-year & Ali and Schaeffer & 561220 & 251598 & 350276 \\
& Polynomial & 566078 & 253456 & 354890 \\
& Guo and Swalve & 570644 & 253884 & 357898 \\
\hline
\end{tabular}

The lowest error variance was also found in this class of models. In all classes of models function of Ali and Schaeffer outperformed other models and resulted in the highest heritability estimates. It can be noticed that for models ignoring hatch-year effects the highest heritability was estimated however they were characterised by lower adequacy. It can be explained by the fact that part of variance resulting from differences between generations was in these models attributed to genetic progress. The repeatability was relatively high comparing to heritability and reached the value of 0.43 in K66 line. Repeatability was stable between classes of models but it was consistently lower for models using regression of Wilmink. It confirms worse fit of Wilmink's model to describe egg production. For models including hatch-year effect similar heritability was obtained for the analyzed populations, whereas ignoring of this effect resulted in higher estimates for K66 line. For all models repeatability was the highest in K66 line and the lowest in A22 line.

\section{Discussion}

Fixed regression models with nested covariates have been suggested for evaluation of test day yields in dairy cattle by PTAK and SCHAEFFER (1993) as they take into account the differences in shape of production curve between groups of animals. They have been successfully implemented in routine genetic evaluation of milk production in Canada and Germany (SWALVE, 2000). In Canada they became a step towards 
implementation of random regression models for national evaluation. Fixed regression models were proved to be efficient in exploiting the information from part-production data (MRODE et al., 2002). The study continues the research obtained under repeatability and cumulative models on the same data set (WOLC, 2006). Low heritability $\left(\mathrm{h}^{2}<0.2\right)$ was estimated. Low heritability of egg production under fixed regression models was also reported by ANANG et al. (2001). The estimates for initial egg production or longer periods vary across populations (SZWACZKOWSKI, 2003). For instance, WEI and VAN DER WERF (1993) reported heritability exceeding 0.5 for one of the studied lines. Some authors (WEI and VAN DER WERF, 1993; PRESSINGER and SAVAS, 1997) concluded that estimates of $h^{2}$ decreased with consecutive periods of egg production.

The study confirmed the results of ANANG et al. (2001) who found that monthly models with nested covariates produced slightly higher estimates of heritability than those obtained from the models with non-nested covariates and the model without covariates. So far there are only a few publications reporting genetic parameters of egg production based on the concept of test day record analysis in dairy cattle. However, the achievements in statistical methodology could possibly improve the accuracy and efficiency of selection in laying hens and might become next step in evolution of poultry evaluation (BEAUMONT and CHAPUIS, 2004).

In general, all mathematical models (used for description of egg production over time) lead to satisfactory approximation of real egg production for three studied lines. However, it should be stressed that Ali-Schaeffer function is most adequate. It corresponds with some studies on lactation curves (KISTEMAKER, 1997; PTAK, 2004). On the other hand, from numerical perspective (number of estimated parameters), the function is more computationally demanding compared to other ones. It was concluded the heritability and repeatability estimates were relatively low, except for results obtained by model without hatch-year effect for K66. The models with nested covariates were most adequate. Whereas the Ali-Schaeffer function better described the egg production compared to other curves studied. In general, the regression model methodology can be recommended for genetic evaluation in laying hens.

\section{Acknowledgements}

The authors are grateful to Dr. K. Meyer and Dr. P.H. Sherrod for their computer package programs.

\section{References}

AGRICULTURE DIVISION STATISTICAL BULLETIN:

Production of eggs. December 2004. (2004). http://www.statcan.ca/english/freepub/23-003-XIB/23003-XIB2004012.pdf

AKAIKE, K.:

On entropy maximization principle. In: Krishnaiah, P.R. (ed.) Applications of Statistic, North-Holand Publishing, Amsterdam (1977)

ALI, T.E.; SCHAEFFER, L.R:

Accounting for covariances among test day milk yields in dairy cows. Can. J. Anim. Sci., 67 (1987), 637

AMIN, A.A.: 
Lactation and sample test-day multi-trait animal model for genetic evaluation of somatic cell scores in Hungarian Holstein Friesian crossbreeds. Arch. Tierz., Dummerstorf 44 (2001), 263-275

ANANG, A.; MIELENZ, N.; SCHÜLER, L.:

Genetic and phenotypic parameters for monthly egg production in White Leghorn hens. J. Anim. Breed. Genet. 117 (2000), 407-415

ANANG, A.; MIELENZ, N.; SCHÜLER, L.:

Monthly model for genetic evaluation of laying hens. I Fixed regression. Brit. Poultry Sci. 42 (2001), 191-196

BEAUMONT, C.; CHAPUIS, H.:

Genetics and selection of birds: evolution of methods and traits. (Génétique et sélection avicoles: évolution des méthodes et des caractères.) INRA Prod. Anim., 17 (2004), 35-43

GŁÓWNY URZĄD STATYSTYCZNY:

The scale of animal production in 2004. (Fizyczne rozmiary produkcji zwierzęcej w 2004r.) (2005)

http://www.stat.gov.pl/dane_spol-gosp/rolnic_lesnict_srodowi/fiz_rozm_prod_zwierz/2004/

GUO, Z.; SWALVE, H.H.:

Modelling of the lactation curve as a sub-model in the evaluation of test day records. INTERBULL Mtg., Prague, Sept. 7-8. INTERBULL Bull. No. 11. Int. Bull Eval. Service, (1995), Uppsala, Sweden.

HORSTICK, A.; DISTL, O.:

Schätzung genetischer Parameter für Testtagsergebnisse der Milchleistung bei ostfriesischen Milchschafen mit Bayes-Methoden für longitudinale Daten. Arch. Tierz., Dummerstorf 45 (2002), 6168

HUISMAN, A.:

Genetic analysis of growth and feed intake patterns in pigs. PhD Thesis, Wageningen University, The Netherlands, (2002)

JAMROZIK, J.; KISTEMAKER G.J.; DEKKERS, J.C.M.; SCHAEFFER L.R.:

Comparison of possible covariates for use in a random regression model for analyses of test day yields. J. Dairy Sci. 80 (1997), 2550-2556

JENSEN, A.:

Durbin Watson Statistic. (2005), http://www.csus.edu/indiv/j/jensena/mgmt105/durbin.htm

JOHNSON, D.L.; THOMPSON, R.:

Restricted Maximum Likelihood estimation of variance components for univariate animal models using sparse matrix techniques and average information. J. Dairy Sci. 78 (1995), 449-456

KISTEMAKER, G. J.:

The comparison of random regression test day models and 305-day model for evaluation of milk yield

MEYER, K; in dairy cattle. PhD thesis, University of Guelph, (1997) Canada.

DFREML ver. 3.1. University of New England, Australia (2001).

MRODE, R.A.; SWANSON, G.J.T.; LINDBERG, C.M.:

Efficiency of part lactation test day records for genetic evaluations using fixed and random regression models. Anim. Sci. 74 (2002), 189-197

NURGIARTININGSIH, V.A.M.; MIELENZ, N.; PREISINGER, R.; SCHMUTZ, M.; SCHÜLER, L.: Genetic parameters for egg production and egg weight of laying hens housed in single and group cages. Arch. Tierz., Dummerstorf 45 (2002), 501-508

NURGIARTININGSIH, V.A.M.; MIELENZ, N.; PREISINGER, R.; SCHMUTZ, M.; SCHÜLER, L.: Heritabilities and genetic correlations for monthly egg production and egg weight of White Leghorn hens estimated based on hen-housed and survivor production. Arch. Gefl. 69 (2005), 98-102

PREISINGER, R.; SAVAS, T.:

Vergleich zweier Methoden zur Schätzung der Varianzkomponenten für Leistungmerkmale bei Legehennen. Züchtungskunde 69 (1997), 142-152

PTAK, E.

Genetic evaluation of dairy cattle using test day yields. Annales of the Hugo Kołłataj Agricultural University of Cracow 298 (2004) - in Polish with English summary

PTAK, E.; SCHAEFFER, L.R.:

The use of test day yields for genetic evaluation of dairy sires and cows. Livest. Prod. Sci. 34 (1993), 23-34

SCHAEFFER, L.R.; JAMROZIK, J.; KISTEMAKER, G.J.; VAN DOORMAAL, B.J.:

Experience with a Test-Day Model. J. Dairy Sci. 83 (2000), 1135-1144

SHERROD, P.H.:

Nonlinear Regression Analysis Program, NLREG version 4.1. Philip H. Sherrod. Nashville. TN. (1998)

SAVAS, T.; PREISINGER, R.; RŐHE, R.; KALM, E.:

Genetische Parameter und optimale Prüfdauer für Legeleistung anhand von Teillegeleistungen bei Legehennen. Arch. Tierz., Dummerstorf 41 (1998), 421--432 
SWALVE, H.H.:

Theoretical Basis and Computational Methods for Different Test-Day Genetic Evaluation Methods. J Dairy Sci. 83 (2000), 1115-1124

SZWACZKOWSKI, T.:

Use of mixed model methodology in poultry breeding: estimation of genetic parameters. In: Poultry Genetics, Breeding and Biotechnology (eds. W.M. Muir, S.E. Aggrey) CAB International (2003), 165202

WEI, M., VAN DER WERF, H. J.:

Animal model estimation of additive and dominance variances in egg production traits of poultry. $\mathrm{J}$. Anim. Sci. 71 (1993), 57-65

WILMINK, J.B.M.:

Adjustment of test-day milk, fat and protein yields for age, season and stage of lactation. Livest. Prod. WOLC, A.: Sci. 16 (1987), 335

Regression methods in genetic evaluation of laying hens. Ph.D. thesis. August Cieszkowski Agric. Univ. Poznan, Poland (2006) - in Polish with English summary

YANG, N.; WU, C.; MCMILLAN, I.:

ZIĘBA G.:

A new mathematical model of poultry egg production. Poultry Sci. 68 (1989), 476-481

Prediction of total egg production based on individual part-record production. PhD Thesis, Agricultural University of Lublin, Poland, (1990) - in Polish with English summary.

Received: 2005-12-19

Accepted: 2006-11-20

Authors' addresses

Prof. Dr. habil. TOMASZ SZWACZKOWSKI*

Department of Genetics and Animal Breeding

Wołyńska 33, 60-637 POZNAŃ, POLAND

* Corresponding Author

E-Mail: tomasz@jay.au.poznan.pl

ANNA WOLC, MSc

Department of Genetics and Animal Breeding

Wołyńska 33, 60-637 POZNAŃ, POLAND

E-Mail: awolc@jay.au.poznan.pl

Dr. MIROSŁAW LISOWSKI

National Research Institute of Animal Production

Poultry Research Branch at ZAKRZEWO, POLAND

E-Mail: mlisowski@izoo.krakow.pl 